\title{
Juridical Analysis of Policy Concerning Oil Palm Estate Management in Indonesia
}

\section{Prischa Listiningrum ${ }^{1}$, Rizqi Bachtiar ${ }^{2 *}$, Dararida Fandra Mahira, ${ }^{3}$ Rumi Suwardiyati ${ }^{4}$}

\footnotetext{
1,3,4 Faculty of Law, Universitas Brawijaya, Malang, East Java, 65145, Indonesia.

${ }^{2}$ Faculty of Social Science and Political Science, Universitas Brawijaya, Malang, East Java, 65145, Indonesia.

*Corresponding author email address rizqi.bachtiar@ub.ac.id
}

\begin{tabular}{|c|c|}
\hline Article & Abstract \\
\hline $\begin{array}{l}\text { Keywords: } \\
\text { CPO; Deforestation; Good } \\
\text { Governance; Indonesia; } \\
\text { Renewable Energy } \\
\text { Directive. } \\
\text { Article History } \\
\text { Received: Nov 17, 2020; } \\
\text { Reviewed: Dec 15, 2020; } \\
\text { Accepted: Jan 1, 2021; } \\
\text { Published: Jan 16, 2021. }\end{array}$ & $\begin{array}{l}\text { The development of the palm oil industry (CPO) in Indonesia is often } \\
\text { confronted by challenges coming from international community, one } \\
\text { of which is the rejection of Indonesian CPO exports declared by } \\
\text { European Union on the grounds of deforestation and land clearing, } \\
\text { specifically forest burning, that are aimed to convert the forest areas } \\
\text { to oil palm estates. In an attempt to clean such a bad name in palm oil } \\
\text { industries in the world and to avert the label 'unsustainable' given by } \\
\text { European Union, President Joko Widodo issued Presidential } \\
\text { Instruction Number } 8 / 2018 \text {. However, the implementation of the } \\
\text { Presidential Instruction is not without hurdles like absence of specific } \\
\text { guidelines to help to implement the policy at regional level and lack of } \\
\text { opportunities to involve civilians to guard this policy. Juridical analysis } \\
\text { of the policy aimed to improve palm oil management and to hamper } \\
\text { deforestation is, thus, required. With normative-juridical method, this } \\
\text { research is aimed to recommend the government to grow the potential } \\
\text { of CPO-based biofuel in Indonesia and the application of one-map } \\
\text { policy over the potential of oil palm estates to allow the } \\
\text { implementation of transparency principle in the structure of good } \\
\text { governance. All these recommendations are mainly aimed to give } \\
\text { more opportunities to the members of public to have a meaningful } \\
\text { participation as well as sustainable and enviro-friendly in improving } \\
\text { the management of palm oil cultivation. }\end{array}$ \\
\hline \multicolumn{2}{|c|}{$\begin{array}{l}\text { (C)2021; This is an Open Acces Research distributed under the term of the Creative Commons } \\
\text { Attribution Licencee (https://Creativecommons.org/licences/by/4.0), which permits unrestricted } \\
\text { use, distribution, and reproduction in any medium, provided the original works is properly cited. }\end{array}$} \\
\hline
\end{tabular}




\section{INTRODUCTION}

The development of palm oil industries (CPO) in Indonesia often faces challenges from economic politics worldwide, where one of the challenges is the rejection coming from European Union against export of CPO from Indonesia. According to the research conducted by European Commission and Non-government Organization vis-à-vis environmental issue, from 1900 to 2000 and 2000 to 2008 deforestation in Indonesia took 3.7 million hectares caused by expansion of plantation for as much as $40 \%$ following the conversion to oil palm plantations (Giuntoli et al., 2010). Moreover, the practice of slash and burn aimed for land clearing is common in both primary forest and peat lands (Jones, 2006);(P. Listiningrum, 2019);(Othman, 2003);(Susanti \& Burgers, 2011);(Tan, 2005). Departing from this research result, European Commission declares Indonesia as the third biggest contributor of $\mathrm{CO}^{2}$ in the world. This situation also poses a threat to biodiversity and decreases the number of endangered animals (European Parliament, 2017). The rejection from European Union results from the issuance of Renewable Energy Directive (RED).

Renewable Energy Directive was initially issued in 2009, and this was aimed to minimize risk of indirect land use change (ILUC) through Renewable Energy Directive 2009/28/EC and Fuel Quality Directive 2009/30/EC. These policies are prepared to simultaneously guard the transition to the development of biofuel. Back in December 2018, European Union issued Renewable Energy Directive 2018/2001 (hereinafter 'the RED II') as a revised version of early regulation, restricting the utilization of biofuel, bioliquid, and biomass fuel that poses high risk to indirect land use change (ILUC). This restriction began in 2019 for the period of 2021-2023 and will end in 2030 where all the members of European Union agree to no longer use biofuel, bioliquid, and biomass fuel that have serious impacts on indirect land use change (ILUC). However, this rule does not apply to biofuel, bioliquid, and biomass fuel with low risk to the land use change (ILUC), including biofuel extracted from oil palm (Maryadi et al., 2019).

This restriction has led to falling figures for foreign exchange and exports by 104.55 millions per year and has cut contribution of oil palm to PDB for about $0.0011 \%$ or equal to 1.63 trillions annually. To sum up, the state has lost IDR 218.18 billions of annual revenue and unemployment is rising. There are 5.8 million hectares of land or $40.56 \%$ of oil palm plantations on which 2.67 million farmers work and contribute $34.51 \%$ to the production of palm oil in Indonesia. In reference to Average Product of Labor (APL), per 5.72 tons will make up to 330 workers redundant every year and twenty farmers are threatened to lose their job (Center for Area Studies Indonesia Institute of Sciences (Center for Area Studies Indonesia Institute of Sciences (P2W-LIPI), 2020).

In an effort to bring back good impression of oil palm in the world and to ward off negative label 'unsustainable' given by European union, on 14 April 2016, President Joko Widodo representing Indonesian Government was committed to temporarily discontinuing license issuance of oil palm plantations and coal industry through Presidential Instruction Number 8 of 2018 concerning Deferral and Evaluation of License Issuance for Oil Palm Estates and Improvement of Productivity in Oil Palm Estates. This instruction details the delay in new license process and investment in the estates located in forest areas, performs evaluation of license and Right to Cultivate (HGU) the oil palm plantation that sit over forest 
areas, distributes lands that are released to the locals, and improves productivity in oil palm plantations under Indonesia Sustainable Palm Oil (ISPO) and reinforces farming organizations (Sawit Watch, 2018).

The contribution of this research is to fill in research gaps on government policies to address the challenges of improving palm oil governance and as an answer to the world's negative campaigns against CPO. Several hurdles are faced in the implementation, involving lack of regional budget spent on the implementation of Presidential Instruction Number 8 of 2018 in regional areas, absence of specific guidelines of the implementation of Presidential Instruction Number 8 of 2018 in regional areas, and unavailability of access of information for civilians on the progress of implementation of Presidential Instruction Number 8 of 2018 as performed by assigned national committee (Sawit Watch, 2019). Therefore, juridical analysis of Indonesian government policies to recover the management of palm oil industries and hamper deforestation is required.

\section{METHOD}

This research refers to normative juridical method or research of doctrinal law that analyzes secondary legal materials (Roni Hanitijo Soemitro, 1998). The approach method used in this research are statute-approach by studying legislation (Peter Mahmud Marzuki, 2007) realted to oil palm governance policy in Indonesia, and conceptual approach by studying and understanding the concepts (Johnny Ibrahim, 2007) of forest governance in Indonesia, forest spatial theory, and aspects of forest governance in Indonesia. All research materials were obtained from documentation, literature review, and the Internet. The documents were then inventoried, classified, and analyzed based on descriptive analysis (Moh Nazir, 2005) aimed to elaborate all the existing legal issues to provide proper solution.

\section{RESULTS AND DISCUSSION}

\section{Prospects of Palm Oil in Indonesia}

Indonesia is rich in both renewable and non-renewable natural resources, and their amount is abundant in land, water, and air all over the archipelago. All this is a gift from God and humans are required to protect, maintain, and conserve this abundance for the whole people of Indonesia, as stipulated in Article 33 paragraph (3) of the 1945 Indonesian Constitution stating "The land and the waters as well as the natural riches therein are to be controlled by the state to be exploited to the greatest benefit of the people."

Contribution coming from oil palm in production of vegetables is massive. In November 2019, palm oil contributed $36.7 \%$, followed by soybean accounting for $27.5 \%$, canola for 13.2\%, and sunflowers for $9.6 \%$ (Databoks, 2019). Palm oil serves as ingredient for processed products such as frying oil, margarine, and cream (Directorate General of Estate Crops, 2020). With all these prospects, Government starts to grow palm oil industry mainly for products that use crude palm oil (CPO) by expanding plantation areas. The areas used to grow oil palm accounted for 14, 326,350 hectares back in 2018 with the largest estates located on the Island of Sumatera (the Province of Riau, North Sumatera, South Sumatera, and Jambi) covering 8,047,920 hectares in 2018 and the Island of Kalimantan (the Province of West Kalimantan, Central Kalimantan, and East Kalimantan) covering 5,588,075 hectares of land in 
the same year (Directorate General of Estate Crops, 2020). With this extended coverage of land, oil palm estates play a major role in providing job in Indonesia. National Development Planning Agency recorded that in 2018 palm oil industries gave job to 16.2 million people (Badan Pengelola Dana Perkebunan Sawit, 2018). Indonesia exports palm oil to countries like Europe, India, and China where palm oil is high selling product (Douglas Sheil, 2009), with Europe as the biggest importer of CPO. The utilization of CPO increases every year along with the growing need in European Union to cultivate CPO into foodstuffs or non-foodstuffs. Europe uses CPO to produce biofuel for transportation (Flach et al., 2015), making palm oil an industry that gives the biggest contribution to foreign exchange; in February 2020, palm oil contributed USD 3.5 billions to foreign exchange.

Palm oil is domestically used as biofuel in Indonesia although the policy governing its utilization began to be introduced in 2015 under the Regulation of Ministry of Energy and Mineral Resources Number 12 aiming 20\% blend (B20) for transportation and industry. In September 2018, the government began to take a further step to target $20 \%$ biodiesel blend for non public service obligation (non-PSO), meaning that this program requires the use of diesel in other sectors other than industry and transportation (Suharsono et al., 2019); (Arya Hadi Dharmawan, 2018).

The step taken by the government to develop biofuel was initiated with the issuance of Presidential Decree Number 46 of 1980 concerning Energy Coordinating Agency (renamed National Energy Council) governing fuel oil saving and Enhancement of the function of Coal in national energy blend. In 1981, National Energy Council made a public policy of energy (KUBE) revised in 2003. Presidential Decree concerning Energy Coordinating Agency has been amended three times and was last revised according to Presidential Decree Number 23 of 2000 (Arya Hadi Dharmawan, 2018).

Biofuel blending target into B30 (a blend of 80\% diesel and 30\% biodiesel) was initiated with the issuance of Presidential Instruction Number 1 of 2006 concerning Provision and Utilization of biofuel as alternative fuel (Lembaga Studi dan Advokasi Masyarakat (ELSAM), 2020). The government also issued Presidential Regulation Number 5 of 2006 concerning National Energy Policy (KEN) validated as Law Number 30 of 2007 vis-à-vis Energy consisting of National Energy Policy drafting. National Energy Policy serves as a guideline of national energy management including the drafting of National Energy General Plan (RUEN) and Regional Energy General Plan (RUED). The need for an agency in charge of control over national energy policy enforcement is growing over time, and this urgency has led to the establishment of energy management agency based on Presidential Instruction Number 26 of 2008 concerning Establishment of National Energy Council, a national, independent, and permanent agency responsible for control over national energy policy

Biofuel development involves upstream and downstream oil gas production, where in the former the government issued Law Number 39 of 2014 concerning Estates and Presidential Regulation Number 66 of 2018 concerning the Second Amendment to Presidential Regulation Number 61 of 2015 concerning Fundraising and Expenses in Oil Palm Estates. 
For downstream production, the government issued Law Number 30 of 2007 concerning Energy, Government Regulation Number 79 of 2014 concerning National Energy Policy (KEN), Regulation of Ministry of Energy and Mineral Resources Number 12 of 2015 concerning Provision, Utilization, and Commerce of Biofuel as alternative fuel, and Regulation of Ministry of Energy and Mineral Resources Number 41 of 2018 in conjunction with Regulation of Ministry of Energy and Mineral Resources Number 45 of 2018 concerning Provision and Utilization of Biodiesel as Biofuel within Financing Framework by Fund Management Agency of Oil Palm Estates (BPDPKS).

\section{Deforestation-related Issues}

Deforestation is a global issue not only hitting the developing countries, but developed ones also receive the impact. Deforestation occurring in Africa accounted for $0.49 \%$ from 2000-2010, followed by Asia with $0.39 \%$ of deforestation, Europe with $0.07 \%$, and South America with $0.45 \%$ per 1000 ha/year (Chakravarty et al., 2012).

The definition of deforestation is implied in the Regulation of Ministry of Environment and Forest Number 70 of 2017 concerning Procedures of Reducing Emission from Deforestation and Forest Degradation, Role of Conservation, Sustainable Management of Forest and Enhancement of Forest Stocks, where deforestation is defined as a permanent change from area with vegetation to that with no vegetation. This is further divided into gross and net deforestation. The former indicates a permanent change of forest cover where reforestation is not considered, while the latter represents a permanent change of forest cover that takes into account reforestation and/or forest plantation (Forest Watch Indonesia, 2020).

The Ministry of Environment and Forestry recorded that Deforestation saw a decrease by 0.4 million hectares from $2013-2014$, followed by another decrease of 1.09 million hectares from 2014-2015, and 0.48 million hectares from 2016-2017 (Forest Watch Indonesia, 2020). With natural forest deforestation definition approach, Indonesian Forest Watch recorded there were increases in deforestation by 126\% and 4\% from 2014-2015 and 2015-2016 respectively and a decrease by 18\% in 2016-2017 (Forest Watch Indonesia, 2020). Based on gross deforestation definition, deforestation saw an increase by 115\% from 2014-2015 and a decrease from 2015-2016 by 33\%, followed by a 19\% decrease from 2016-2017 (Forest Watch Indonesia, 2020). However, based on net deforestation definition approach, deforestation experienced an increase by 175\% from 2014-2015 and a decrease by $42 \%$ and $24 \%$ from 2015 2016 and 2016-2017 respectively (Forest Watch Indonesia, 2020).

By means of natural forest approach, gross and net indicate discrepancies in deforestation figures, but based on natural forest deforestation approach, downward trend in deforestation was seen in the past year within four periods of analysis, and gross and net deforestation definition approach indicates downward trend in deforestation after the third year period within four periods of analysis (Forest Watch Indonesia, 2020).

To date, determining the representative area of oil palm estates still becomes an issue for Indonesia, and this challenge seems to result from different recorded data each institution either from the government or non-government organizations has regarding the area of oil palm plantations (Meijaard et al., 2018). Data from Sawit Watch, for example, recorded that 
the area of oil palm estates reached 22.2 million hectares in 2018 (Sawit Watch, 2019), while on behalf of Indonesian Government, the Directorate General of Plantation stated that the area of the plantations in Indonesia reached 14,326,350 million hectares in the same year (Directorate General of Estate Crops, 2020). From the data issued by both the government and NGO, there is a huge discrepancy of 7,673,650.2 million hectares.

This massive discrepancy results from different methods employed by each organization in data processing. Another factor like lack of transparency and criteria agreed upon regarding data processing also seem to have contributed to this difference among organizations. This gap has slowed down the development of the oil palm estates in Indonesia, where this issue involves overlapping license in land concession or an issue related to spatial planning in regions (Rachmad Safa'at, 2017). All these problems lead further to land clearing with clear-cutting method, Absence of Free Prior Informed Consent (FPIC) about the lands owned by indigenous people, unavailability of access to information, expansion held by small holders, absence of mechanism to resolve land-related conflict, oil palm plantation in forest areas, and illicit oil palm plantations (Sawit Watch, 2018); (Forest Watch Indonesia, 2018).

\section{Government Policies aimed to improve Management of Palm Oil Industry and to hamper Deforestation}

Intending to tackle the existing problem concerning permit, on 14 April 2016 President Joko Widodo set a commitment to temporarily discontinuing license issuance process for oil palm estates and coal that is in place based on Presidential Instruction Number 8 of 2018 concerning Deferral and Evaluation of License Issuance for Oil Palm Estates and Improvement of Productivity in Oil Palm Estates. The regulations in the presidential instruction involve: (1) deferring new license issuance process or investment in oil palm estates in forest areas, (2) Evaluating license or Cultivation Rights Title to oil palm estates in forest areas, distributing lands of oil palm estates released to people, and (3) Improving productivity of oil palm estates through Indonesia Sustainable Palm Oil (ISPO) Policy and reinforcing farming organizations (Sawit Watch, 2018). The implementation of the presidential instruction is not without any hampering problems such as lack of funding in regional areas to back up the implementation of the instruction, the absence of special guidelines of implementation of the presidential instruction, and no access to information for civilians on the progress of the implementation performed by national committee (Sawit Watch, 2019).

The government also issued ISPO in 2011 based on the Regulation of Ministry of Agriculture Number 11/Permentan/OT.140/2015 concerning System of Certification of Sustainable Oil Palm in Indonesia (KPK, 2016). The ISPO is issued by the government to set a standard that oil palm estates must comply with for sustainability and to improve the sustainability of palm oil commodity (Sawit Watch, 2018). The ISPO must be followed by enterprises running oil palm estates but small oil palm plantations can voluntarily follow this standard. The Regulation of Ministry of Regulation Number 11/2015 implies that this voluntary compliance with the standard only applies to the plantations utilizing plasma systembased cultivation and to reserve lands owned by the government, a plantation company, or community plantations, or to lands that produce palm oil for renewable energy. This ISPO policy holds the principle that covers the legality required in oil palm estates, the management, 
the protection of primary forest and peat forest utilization, cultivation and utilization of environment, Responsibility over workers, social responsibility, public empowerment, and continual improvement of enterprises (KPK, 2016). The enforcement of ISPO has been very sluggish. In 2016, for example, there were 800 companies halted in registration process, and 115 companies were stuck in evaluation stage. Another challenge is that the commission of ISPO holds an excessive authority that hampers performance, and this situation has led to another problem for ISPO commission to maintain independence and credibility. In the meantime, the ISPO commission is authorized to form ISPO secretariat, evaluating team, Committee dealing with resolution to certification-related grievances, to assure personnel assigned in organizations in charge of certification and consultation, training organizations, to assure auditors and consultants, and to form panels in arbitration/appeal (Forest Watch Indonesia, 2017).

Indonesian Government also establishes Peat Restoration Agency under Presidential Regulation Number 1 of 2016 concerning Peat Restoration Agency. In line with the presidential regulation, this agency is in charge of coordination and facilities of peat restoration in the Province of Riau, Jambi, South Sumatera, West Kalimantan, Central Kalimantan, South Kalimantan, and Papua, where the policy of peat restoration is reinforced, plan and control are set, and partnership in arrangement of peat restoration is established, peat hydrology is mapped, protected and cultivation areas are established, infrastructure to rewet peat is constructed, management of burnt areas is re-planned, people's awareness is raised, education is reinforced, construction is performed, infrastructure in lands obtained from concession is maintained, and other measures mandated by the President are taken. Selecting regions where restoration takes place is performed based on criteria set by Peat Restoration Agency involving burnt areas in 2015, peat dome with canals, and shallow peat cultivation (Peat Restoration Agency, 2019). Performance of Peat Restoration Agency from 2017-2018 is represented in the following Table:

Performance in Peat Restoration 2017-2018

Data per Province for Affected Lands (in Hectares)

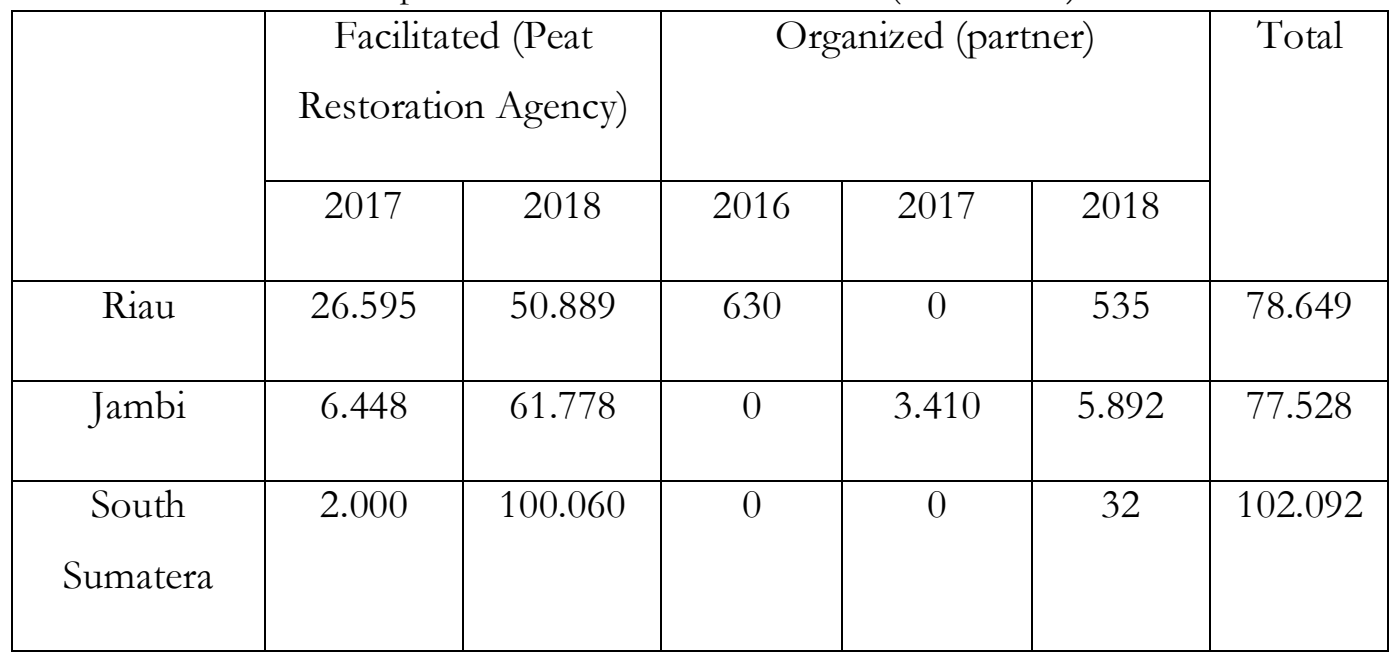




\begin{tabular}{|c|c|c|c|c|c|c|}
\hline $\begin{array}{c}\text { West } \\
\text { Kalimantan }\end{array}$ & 3.114 & 16.805 & 0 & 0 & 25.950 & 45.869 \\
\hline $\begin{array}{c}\text { Central } \\
\text { Kalimantan }\end{array}$ & 62.126 & 72.754 & 1.924 & 91.809 & 138.133 & 366.746 \\
\hline $\begin{array}{c}\text { South } \\
\text { Kalimantan }\end{array}$ & 3.193 & 4.560 & 157 & 0 & 0 & 7.918 \\
\hline Papua & 0 & 1.100 & 0 & 0 & 0 & 1.100 \\
\hline Total & 103.476 & 307.953 & 2.711 & 95.219 & 170.542 & 679.901 \\
\hline
\end{tabular}

Table 1. Performance in Peat Restoration by Peat Restoration Agency 2017-2018

Source: Peat Restoration Agency, 2019

Peat restoration faces some challenges hampering it from optimal performance. The policy issued by the Ministry of Agriculture concerning oil palm replantation seems to target peat lands. Another problem is concerning the fund allocated for peat restoration that seems to decrease every year. In 2018 budget of Peat Restoration Agency was mostly allocated to Regional Governments for the development of canal bulkheads and drilled wells (Indra Nugraha, 2020). With this budget reduction, of course, it is very much in line with the performance of the Peat Restoration Agency which as a result the Peat Restoration Agency has to seek budget funds from several partners. And if you look at table 1, it can be seen that two areas are funding in peat recovery coming from partners, namely from West Kalimantan and Central Kalimantan in 2018.

The measures taken by the government to maintain the management of oil palm estates and to minimize deforestation are based on ethics and moral value for improvement. The concept of good governance is expected to lead further to fair government. Some measures to resolve oil palm estates-related problems are required to cope with overlapping license for available lands and use of lands. In practice, improvement efforts are needed to solve the problem of oil palm in Indonesia. This is intended to overcome the problem of overcoming overlapping land licensing and land use as available as its function. It is essential that one map policy concerning the potential of oil palm estates be made to allow the implementation of transparency in good governance (Prischa Listiningrum \& Bachtiar, 2018). Thus, it will also allow public to have a meaningful participation in improving oil palm estates as sustainable and excellent commodity that is more enviro-friendly.

\section{CONCLUSION}

The presidential instruction as a response to negative campaigns worldwide against the commodity of palm oil in Indonesia faces some hurdles in the implementation where regional fund is not specifically allocated for the implementation of this presidential instruction in 
regional areas. Moreover, special guidelines of the implementation of Presidential Regulation in regional areas are not made available, nor is the access to the information for civilians on the progress of implementation of Presidential Instruction Number 8 of 2018 performed by national committee. Frthermore, the enforcement of ISPO policy is considered too slow. A different policy issued by the Ministry of Agriculture concerning oil palm replantation presents a problem when Peat Restoration Agency is active since it targets peat lands. The fund allocated for peat lands seemingly keep decreasing every year, and the budget of Peat Restoration Agency was majorly allocated to regional regulations to build canal bulkheads and to drill wells.

Therefore, one map policy is certainly required in the future regarding the potential of oil palm estates to allow transparency in good governance. It is also expected that public can have a meaningful participation in improving the management of palm oil as an excellent commodity that is sustainable and more enviro-friendly.

\section{ACKNOWLEDGMENTS}

Gratitude is addressed to Universitas Brawijaya for funding this research.

\section{REFERENCES}

Arya Hadi Dharmawan, et al. (2018). Pengembangan bioenergi di Indonesia: Peluang dan tantangan kebijakan industri biodiesel. Pengembangan Bioenergi Di Indonesia: Peluang Dan Tantangan Kebijakan Industri Biodiesel. https://doi.org/10.17528/cifor/006975

Badan Pengelola Dana Perkebunan Sawit. (2018). Industri Kelapa Sawit Indonesia Serap 16,2 Juta Pekerja. https://www.bpdp.or.id/Industri-Kelapa-Sawit-Indonesia-Serap-16-2-JutaPekerja

Center for Area Studies Indonesia Institute of Sciences (P2W-LIPI). (2020). Potensi Dampak Penerapan RED II Terbadap Perekenomian Indonesia. http://psdr.lipi.go.id/news-andevents/opinions/potensi-dampak-penerapan-red-ii-terhadap-perekenomianindonesia.html

Chakravarty, S., K., S., P., C., N., A., \& Shukl, G. (2012). Deforestation: Causes, Effects and Control Strategies. Global Perspectives on Sustainable Forest Management. https://doi.org/10.5772/33342

Databoks. (2019). Produksi Minyak Sawit Memenubi 37\% Minyak Nabati Dunia. https://databoks.katadata.co.id/datapublish/2019/12/07/produksi-minyak-sawitmemenuhi-37-minyak-nabati-dunia

Directorate General of Estate Crops. (2020). Tree Crop Estate Statistics of Indonesia. Tree Crop Estate Statistics of Indonesia 2018-2020, 1-82. https://drive.google.com/file/d/1FVxpBNihnuB3ayAALBi-FtsBShIUxMTD/view

Douglas Sheil, et al. (2009). The impacts and opportunities of oil palm in Southeast Asia: What do we know and what do we need to know? In The impacts and opportunities of oil palm in Southeast Asia: What do we know and what do we need to know? https://doi.org/10.17528/cifor/002792

European Parliament. (2017). on palm oil and deforestation of rainforests (2016/2222(INI)). 
https://www.europarl.europa.eu/doceo/document/A-8-2017-

0066_EN.html?redirect\#title1

Flach, B., Lieberz, S., Rondon, M., Williams, B., \& Teiken, C. (2015). EU Biofuels Annual 2015. Global Agricultural Information Network, 42. http://gain.fas.usda.gov/Recent GAIN Publications/Biofuels Annual_The Hague_EU-28_7-15-2015.pdf

Forest Watch Indonesia. (2017). 6 Tabun ISPO.

Forest Watch Indonesia. (2018). Roadmap Masyarakat Sipil untuk Reforma Perkebunan Sawit Indonesia Berkeadilan.

Forest Watch Indonesia. (2020). Menelisik Angka Deforestasi Pemerintah. https://fwi.or.id/menelisik-angka-deforestasi-pemerintah/\#: :text=Berdasarkan hasil pembahasan diatas $\% 2 \mathrm{C}$ pada, angka 650 ribu hektare pertahun.

Giuntoli, J., Agostini, A., Edwards, R., Marelli, L., European Commission, Broeren, M. L. M., Molenveld, K., van den Oever, M. J. A., Patel, M. K. M. K., Worrell, E., Shen, L., Tsiropoulos, I., Faaij, A. P. C., Lundquist, L., Schenker, U., Briois, J. F., Patel, M. K. M. K., Galloway, J. N., Dentener, F. J., ... IPCC. (2010). Communication from the Commission to the European Parliamant, the Council, the European economic and social committee and the committee of the regions. A European Strategy for plastics in a Circular Economy. https://doi.org/10.2779/822269

Indra Nugraha. (2020). Empat Tabun BRG: Daya dan Upaya Pulibkan Gambut Negeri. Mongabay.Co.Id. https://www.mongabay.co.id/2020/01/28/empat-tahun-brg-dayadan-upaya-pulihkan-gambut-negeri/

Johnny Ibrahim. (2007). Teori dan Metodologi Penelitian Hukum Normatif. Malang, Bayumedia.

Jones, D. S. (2006). ASEAN and transboundary haze pollution in Southeast Asia. Asia Europe Journal, 4(3), 431-446. https://doi.org/10.1007/s10308-006-0067-1

KPK. (2016). Kajian sistem pengelolaan komoditas kelapa sawit. 65.

Lembaga Studi dan Advokasi Masyarakat (ELSAM). (2020). Identifikasi Modalitas dan Hambatan Kepatuban Pertamina sebagai Aktor Pemajuan Hak. Asasi Manusia dan Produk Berkelanjutan.

Listiningrum, P. (2019). Transboundary civil litigation for victims of Southeast Asian Haze pollution: Access to justice and the non-discrimination principle. Transnational Environmental Law, 8(1). https://doi.org/10.1017/S2047102518000298

Listiningrum, Prischa, \& Bachtiar, R. (2018). The Emergence of Access to Environmental Justice in Indonesia (A Case Study on Mining for Cement in Kendeng Mountains). 59(December 2012), 236-240. https://doi.org/10.2991/iceml-18.2018.52

Maryadi, H. L. P., Dewi, Elizabeth Diana Purwaning, H. L. A., Dewi, A. R., Fitri, W., Putro, R. A., Priyantari, Y. R., \& Abdullah, Hudzaifah Kurniawan, H. (2019). "Peran Diplomasi dalam Mendukung Tujuan Pembangunan Berkelanjutan: Tinjauan terbadap Pengelolaan Industri Minyak Nabati ."

Meijaard, E., Garcia-Ulloa, J., Sheil, D., Wich, S. A., Carlson, K. M., Juffe-Bignoli, D., \& Brooks, T. (2018). Kelapa sawit dan Keanekaragaman Hayati.

Moh Nazir. (2005). Metode Penelitian. Jakarta, Ghalia Indonesia

Othman, J. (2003). Linking Agricultural Trade, Land Demand, and Environmental Externalities: Case of Oil Palm in Southeast Asia. Asean Economic Bulletin, 20(3), 244-255. 
Peat Restoration Agency. (2019). Laporan 3 Tabun Restorasi Gambut. Laporan, Badan Restorasi Gambut

Peter Mahmud Marzuki. (2007). Penelitian Hukum. Jakarta, Kencana.

Rachmad Safa'at, et. al. (2017). Analisis Implementasi Putusan Mabkamab Konstitusi atas Pengelolaan Sumber Daya Alam. Laporan Penelitian, Pusat Penelitian dan Pengkajian Pengelolaan Teknologi Informasi dan Komunikasi Sekeretariat Jenderal Mahkamah Konstitusi.

Roni Hanitijo Soemitro. (1998). Metodologi Penelitian Hukum dan Jurimetri. Jakarta: Penerbit Ghalia.

Sawit Watch. (2018). Membumikan Moratorium Dan Evaluasi Perkebunan Sawit. Policy Brief, Koalisi Masyarakat Sipil untuk Moratorium Kelapa Sawit Indonesia.

Sawit Watch. (2019). Shadow Report: Kemana Arah Implementasi Inpres No. 8 Tahun 2018 Berjalan? In Sawit Watch. Shadow Report, Koalisi Masyarakat Sipil.

Suharsono, A., et al. (2019). Getting to 23 Per Cent: Strategies to scale up renewables in Indonesia. Report, International Institute for Sustainable Development.

Susanti, A., \& Burgers, P. (2011). Oil palm expansion in Riau province, Indonesia : serving people, planet, profit ? Report. European Union.

Tan, A. (2005). The ASEAN agreement on transboundary haze pollution: Prospects for compliance and effectiveness in post-Suharto Indonesia. New York University Environmental Law Journal, 1, 647-721. 